\title{
Liter per Nanogram per Minute
}

National Cancer Institute

\section{Source}

National Cancer Institute. Liter per Nanogram per Minute. NCI Thesaurus. Code C85687.

Liters per nanogram per minute. 